\title{
Bitter acids from hydroethanolic extracts of Humulus lupulus L., Cannabaceae, used as anxiolytic
}

\author{
Giuseppina Negri," Daniel di Santi, Ricardo Tabach \\ Departmento de Psicobiologia, Universidade Federal de São Paulo, Rua Botucatu 862, \\ Edifício Ciências Biomédicas, $1^{\circ}$ andar, 04023-062 São Paulo-SP, Brazil.
}

\begin{abstract}
RESUMO: Humulus lupulus L., Cannabaceae, é usada como sedativo e ansiolítico na medicina popular. O método de HPLC-DAD-ESI-MS ${ }^{\mathrm{n}}$ representa uma ferramenta poderosa para a análise de produtos naturais, desde que ela fornece o espectro de UV e informações estruturais sobre os constituintes da mistura. O objetivo deste trabalho foi o de caracterizar os constituintes encontrados no extrato hidroalcoólico. Os constituintes 1-9 foram tentativamente caracterizados através do UV/DAD e ionização por electrospray (MS/MS) depois da separação usando fase reversa, tempo de retenção e dados da literatura. Os principais compostos fenólicos (baseados na área dos picos) foram caracterizados como ácido hulupínico (9), coulupona (8), dois alfaácidos amargos oxidados (principais constituintes), um deles sendo um derivado da coumulinona oxidada (5) e o outro um derivado da humulinona oxidada (7), junto com uma procianidina B (3) e os flavonoides rutina (4) e o canferol-7-O-rutinosídeo (6). Esta planta conhecida devido às suas propriedades ansiolíticas e por ser um componente da cerveja, mostrou derivados oxidados de alfa-ácidos, como principais constituintes do extrato hidroalcoólico.
\end{abstract}

Unitermos: Humulus lupulus, flavonoides glicosídeos, derivados de alfa-ácidos amargos oxidados, $\mathrm{HPLC} / \mathrm{DAD} / \mathrm{MS} / \mathrm{MS}$

\begin{abstract}
Humulus lupulus L., Cannabaceae, is commonly used as light sedative and anxiolytics in folk medicine. HPLC-DAD-ESI-MS ${ }^{\mathrm{n}}$ represents a powerful tool for the analysis of natural products, since it can simultaneously provide a UV chromatogram and significant structural information about compounds in complex mixture. The aim of this work was characterize the constituents present in hydroethanolic extract. Compounds 1-9 were tentatively characterized on the basis of UV, MS/MS, after reversed phase separation, retention time and literature data. The main phenolic compounds (based on peak area) were characterized as hulupinic acid (9), cohulupone (8), two oxidized hop alfa-bitter acids (principal constituents), one being a oxidized cohumulinone (5) and the other an oxidized humulinone (7) derivatives, together with a procyanidin dimer B (3), flavonoids rutin (4) and kaempferol-7-O-rutinoside (6). This plant known, due to anxiolytic property and beer flavoring, showed oxidized hop bitter acids, as principal constituents, in its hydroethanolic extract.
\end{abstract}

Keywords: Humulus lupulus, flavonoid glycosides, oxidized hop bitter acids, HPLC/DAD/MS/ MS.

\section{INTRODUCTION}

Humulus lupulus L., Cannabaceae, (commonly named hops) is natural from central Europe and it is widely cultivated throughout the temperate regions of the world (Heinrich et al., 2004, Zanoli \& Zavatti, 2008). The hop is one of major raw material in brewing, therefore, the economic value of the hop plant is derived from its worldwide application as an essential flavoring ingredient for the brewing of beer. The impact of hops on beer quality is manifold, but by far, most important are specific features attributed to beer flavor including bitter taste and hoppy aroma. Many hop bittering compounds were early discovered by Verzele \& De Keukeleire (1991). The hop bitter acids are alicyclic phenolic acids, which are, respectively, di- or tri-prenylated phloroglucinol derivatives and their oxidation products (Chen \& Lin, 2004; Stevens \& Page, 2004). In general, two major $\alpha$ and $\beta$-acids are in hop. The two series comprise, in fact, three constituents differing in the nature of the side chain (De Keukeleire et al., 2003). They are $\alpha$-acids with three major analogous (cohumulone, humulone and adhumulone) 
and $\beta$-acids also with three major analogous (colupulone, lupulone and adlupulone) with a six-membered ring structure (De Keukeleire et al., 2003). The $\beta$-acids differ structurally from the $\alpha$-acids by having one more prenyl group. In addition, there are several homologues and analogues including posthumulone/postlupulone, prehumulone/prelupulone and adprehumulone (Ciochina \& Grossman, 2006; Khatib et al., 2006).

Cohumulinone and humulinone are two corresponding oxidation products from $\alpha$-acids in five member ring structure. Likewise, there are cohulupone and hulupone the oxidation corresponding to colupulone and lupulone/adlupulone in five member ring structure (De Keukeleire, 2000). The $\alpha$-acids and the corresponding iso- $\alpha$-acids, as well as the $\beta$-acids, each occur in six different congeners differing in the carbon skeleton of the alkanoyl side chain. During the brewing process the water insoluble $\alpha$-acids of the hop extract are converted into the more soluble iso- $\alpha$-acid. Isomerization of $\alpha$-acids generated cis/trans iso- $\alpha$-acids in a five member ring structure. A remarkable instability of $\alpha$-acids and trans-iso- $\alpha$-acids during beer storage was found to be independent from the nature of the alkanoyl side chain (Intelmann et al., 2009).

The most important chemical conversion that occurs in Hops is the thermal isomerization of the $\alpha$-acids or humulones to the iso- $\alpha$-acids or isohumulones via an acyloin-type ring contraction. Isohumulones are optically active molecules which occur as cis- and transisomers and gives rise to two epimeric isohumulones, which are distinguished as cis-isohumulones and transisohumulones, depending on the spatial arrangement of the tertiary alcohol function at $\mathrm{C}(4)$ and the prenyl side chain at $C(5)$ (Bohr et al., 2008). Tetrahydro-iso- $\alpha$-acids are obtained by hydrogenation of the double bonds in the side chains of the iso- $\alpha$-acid and hexahydro-iso- $\alpha$ acids are accessible by a combination of the reduction of the side-chain carbonyl group and hydrogenation of the double bonds (De Keukeleire, 2000). Iso- $\alpha$ and reduced iso- $\alpha$-acid contribute to bittering values and antimicrobial property in beer and are easily deprotonated, being commonly referred to as acids, due to their beta triketo moiety (Garcia-Villalba et al., 2006; Hall et al., 2008), having pronounced bacteriostatic activity; they strongly inhibit the growth of Gram-positive bacteria (De Keukeleire, 2000).

Bitter acids can be used as potential cancer chemopreventive agents (Gerhauser, 2005) and in recent years, hops have gained considerable interest due to the biological and potential cancer chemopreventive activities of some of their constituents (Bohr et al., 2008). Humulone possess antioxidative, anti-inflammatory and other biologically active activities, such as, antitumorpromoting effects on mouse skin carcinogenesis (Lee et al., 2007; Van Cleemput et al., 2009).

The main constituents found in essential oils of H. lupulus are humulene and myrcene (Zanoli et al., 2007; Chadwick, 2006). Prenylated flavonoids, other major components of this species, may be divided into two major groups, prenylated chalcones and prenylated flavanones such as, 6-prenylnaringenin, 8-prenylnaringenin and 8-geranylnaringenin (Nikolic et al., 2005; Vogel \& Heilmann, 2008). Anti proliferative and apoptosis-inducing effects had been attributed to side chain variants of prenylflavanones (Diller et al., 2007; Magalhães et al., 2008; Mendes et al., 2008). Resveratrol and its piceid derivative were also identified in hop (Schwekendiek et al., 2007). Content of $\alpha$-acids, $\beta$-acids, desmethylxanthohumol, and xanthohumol can vary with cultivation and climatic conditions (De Keukeleire et al., 2007).

Proanthocyanidins, also named condensed tannins (Li \& Deinzer, 2006; Callemien \& Collin, 2008), phenolic acids (ferulic and chlorogenic acids) (Zanoli et al., 2007; Li \& Deinzer, 2006; Callemien \& Collin, 2008) and flavonoid aglycones and glycosides, (Segawa et al., 2006; Arraez-Roman et al., 2006) are also found in H. lupulus. Proanthocyanidins exhibited a wide range of biological activities, such as antioxidants offering protection against cardiovascular and neurodegenerative diseases and immune disorders (Garcia-Villalba et al., 2006). In hop strobilus (H. lupulus) collected in Estonia, xanthohumol, humulol, cohumulone, humulone, prehumulone, colupulone, lupulone, prelupulone and sesquiterpenoic acid were found (Helmja et al., 2007).

Gamma-aminobutyric acid (GABAA) receptors had been widely studied since they are the site of action of a number of clinically important drugs, including benzodiazepines, barbiturates, and anesthetics (Morris et al., 2006). Benzodiazepines are the first-line drugs for the treatment of anxiety disorders, acting at the GABAA receptors which remain primary targets for novel anxiolytic compounds. These compounds are thought to produce their pharmacological effects by binding to a benzodiazepine recognition site on the GABAA receptor complex, facilitating the inhibitory activity of GABA. Furthermore, a long-term benzodiazepines use induces tolerance and dependence (Ennaceur et al., 2008).

Hyphenated techniques, such as HPLC with UV photodiode array detection and HPLC/ESI/MS/ MS are powerful analytical tool for plant analyses. Recently, the optimization of the chromatographic separation parameters as well as the advantage of mass spectrometric detection significantly improved selectivity and sensitivity of the analysis of $\alpha$-/ $\beta$-acids and iso- $\alpha$ acids. In brewing industry, these techniques had been developed for analysis of hops, hop compounds, and polyphenols (Intelmann et al., 2009; Jaskula et al., 2009; Callemien \& Collin, 2008).

The purpose of this investigation was to characterize the constituents present in hydroethanolic extract of $H$. lupulus combining data obtained by DAD 
and electrospray ionisation MS/MS after separation by reversed-phase HPLC and correlate these constituents, such as flavonoids and oxidized bitter acids with the anxiolytic effects observed in biological tests after the oral administration of this extract.

\section{MATERIAL AND METHODS}

\section{Material}

The flowers and leaves of Humulus lupulus L., Cannabaceae, were acquired from Quimer Ervas \& Especiarias S. A. The species came with their respective certificate. Rutin and others standards were purchased from Sigma-Aldrich Chemical CO. (St. Louis, MO, USA); and HPLC grade methanol from Merck (Darmstadt, Germany). HPLC grade water was prepared from distilled water using a Milli-Q system (Millipore, Waters, Milford, MA, USA).

\section{Extraction}

Fresh flower and leaves were air-dried in the shade at room temperature to a constant weight, ground to pass through a 30 mesh screen and stored in sealed glass vials. For the preparation of lyophilizate extract, $100 \mathrm{~g}$ of the powder of dried flower and leaves was extracted with 1 L of hydroethanolic solution $50 \%$ (V/V), by maceration (Mendes et al., 2002). The crude preparation was filtered through Whatman paper no 1 . The solvent was concentrated in a rotaevaporator to produce a crude extract, which was placed in a lyophilizator (4 atm of pressure and temperature of $-40{ }^{\circ} \mathrm{C}$ ) for $48 \mathrm{~h}$ to obtain the lyophilized extract, which was then stored in amber flaks at $-5{ }^{\circ} \mathrm{C}$ (freezer).

\section{Phytochemical screening}

The lyophilized hydroethanolic extract of $H$. lupulus was screened via thin layer chromatography (TLC), for alkaloids, phenolic acids, steroids, terpenoids, cardioactive glycosides, flavonoids, coumarins, saponins, lignans, tannins and iridoids according to Stahl (1969) and Wagner \& Bladt (1996). The extract was dissolved in methanol $(10 \mathrm{mg} / \mathrm{mL})$ and applied to Silica-gel $60 \mathrm{~F}_{254}$ plates (Merck). Solution standards of pure compounds were prepared at a concentration of $1 \mathrm{mg} / \mathrm{mL}$. The alkaloid analysis was carried out based on method of $\mathrm{Xu}$ et al. (2006) with minor modifications. Lyophilizate extract $(20 \mathrm{mg}$ ) was dissolved in $2 \mathrm{~mL}$ of water to form a suspension that was acidified with a solution of $20 \%$ of sulfuric acid $\left(\mathrm{H}_{2} \mathrm{SO}_{4}\right)$ to $\mathrm{pH} 4$. The acidic suspension was first partitioned with ethyl acetate (EtOAc) to remove neutral components, and the aqueous phase was then basified with sodium carbonate $\left(\mathrm{Na}_{2} \mathrm{CO}_{3}\right)$ to $\mathrm{pH} 10$ followed by extraction with chloroform in order to obtain the fraction of alkaloids.

\section{Hydrolysis experiments}

The free flavonoid aglycones of flavonoids $O$-glycosides were released by acidic hydrolysis as follows: $50 \mathrm{mg}$ of the lyophilized extract was dissolved in $4 \mathrm{~mL}$ of $10 \%(\mathrm{v} / \mathrm{v}) \mathrm{H}_{2} \mathrm{SO}_{4}$, and heated in boiling water for $1 \mathrm{~h}$. After cooling, the reaction mixture was neutralized with saturated aqueous sodium carbonate and filtered under reduced pressure. The filtrate was concentrated to approximately $1 \mathrm{~mL}$.

\section{HPLC/DAD/ESI/MS/MS analysis}

The lyophilized and hydrolysed extracts were dissolved in water-methanol $(80: 20) \mathrm{v} / \mathrm{v}(4 \mathrm{mg} / \mathrm{mL})$ and filtered with a $0.45 \mu \mathrm{m}$ filter (German Sciences, Tokyo, Japan) prior to injection of $31.2 \mu \mathrm{L}$ into the HPLC system. A DAD SPD-M10AVP Shimadzu equipped with a photodiode array detector was coupled to Esquire 3000 Plus, Bruker Daltonics mass spectrometer and an electrospray ionization (ESI) source. The instrument was controlled by a computer running the SCL-10A VP. The mobile phases consisted of eluent A $(0.1 \%$ aq. formic acid) and eluent $\mathrm{B}$ (methanol). A reverse phase, C18, Zorbax-5B-RP-18 (Hewlett Packard) column (4.6×250 $\mathrm{mm}, 5 \mu \mathrm{m})$ and a linear gradient of $20-90 \%$ B (v/v) over 50 min were utilized for separations, through the following gradient: 0 min $20 \% \mathrm{~B}$ in $\mathrm{A} ; 10 \mathrm{~min} 30 \% \mathrm{~B}$ in A; 20 min $50 \%$ B in A; $30 \min 70 \%$ B in A; $40 \min 90 \%$ $\mathrm{B}$ in $\mathrm{A} ; 45 \min 40 \% \mathrm{~B}$ in $\mathrm{A}$ and finally returned to the initial conditions $(20 \%$ B) to re-equilibrate the column prior to another run. The flow rate was kept constant at $0.5 \mathrm{~mL} \cdot \mathrm{min}^{-1}$ and the temperature of the column was maintained at $28{ }^{\circ} \mathrm{C}$. The diode-array detector (DAD) was working at interval of 200-600 nm and the optical density of the eluate was continuously monitored at wavelengths of 250 (phenolic acids and oxidized bitter acids), 280 (flavanols and bitter acids) and $370 \mathrm{~nm}$ (flavonols). The ionization conditions were adjusted as follows: electrospray ionization was performed using an ion source voltage of $40 \mathrm{~V}$ and a capillary offset voltage of $4500 \mathrm{~V}$. Nebulization was aided with a coaxial nitrogen sheath gas provided at a pressure of 27 psi. Desolvation was facilitated using a counter current nitrogen flow set at a flux of $7.0 \mathrm{~L} / \mathrm{min}$ and a capillary temperature of $325^{\circ} \mathrm{C}$. The flux of LC/MS was $100 \mu \mathrm{L} / \mathrm{min}$. MS data were performed in the positive and negative ion mode. The full scan mass acquisition, in both negative and positive mode were performed by scanning from $\mathrm{m} / \mathrm{z} 100$ up to 900 . Compounds were identified by comparison of their UV and ESI/MS spectra with literature values or by comparison to authentic standards. Relative amounts of constituents in these extracts were assumed to be proportional to the areas under the corresponding chromatogram peaks. 


\section{Specific pharmacological tests}

For the specific pharmacological tests were used male Wistar rats (3-4 month old, 250-400 g), obtained from the Department of Psychobiology, Unifesp, kept in an isolated room with light/dark cycle of $12 \mathrm{~h}$ and constant temperature $\left(23 \pm 2{ }^{\circ} \mathrm{C}\right)$, and water and food $a d$ libitum, except during the period of tests.

The first classical anxyolitic test was the Elevated Plus Maze (EPM) were four groups of ten rats each received orally doses of $250,500,750$ and $1000 \mathrm{mg} / \mathrm{kg}$, respectively, of $H$. lupulus extract. Thirty minutes after administration the animals were introduced in the EPM for $5 \mathrm{~min}$ and the number of entrances and the time of permanence in each one of the four arms of the apparatus were recorded (Handley \& Mithani, 1984; Chacur et al., 1999). Other two groups of ten rats each were administered with diazepam $2 \mathrm{mg} / \mathrm{kg}$ or Passiflora incarnata extract $200 \mathrm{mg} / \mathrm{kg}$ as positive controls.

The second anxyolitic test was the Neophobia test that consists in exposing the animals to a new ambient with novel food, for this test two groups of ten rats each received orally, respectively, water or $750 \mathrm{mg} /$ $\mathrm{kg}$ of $H$. lupulus extract; 60 min after the administration the animals were placed in individual cages with a bottle of water:diluted sweetened milk solution $(2: 1)$. The intake of this solution was measured at 15, 30 and 60 min (Cowan, 1977; Carlini \& Burgos, 1979). Two extra groups of rats received diazepam $2 \mathrm{mg} / \mathrm{kg}$ and Passiflora incarnata $200 \mathrm{mg} / \mathrm{kg}$ as positive controls.

\section{RESULTS AND DISCUSSION}

The hydroethanolic extract had an acidic $\mathrm{pH}$ (5.5) and was obtained with a yield of $9.6 \mathrm{~g}$ per $100 \mathrm{~g}$ of crude plant material. To characterize the qualitative chemical profile, the bioactive extract was initially analyzed via thin-layer chromatography (TLC) (Stahl, 1969; Wagner \& Bladt, 1996). Dried TLC plates were sprayed with specific reagents and heated to observe the color reaction. The spots of procyanidins exhibited a pink color upon heating with $2 \mathrm{~N}$ methanolic hydrochloric acid. This extract also reacted positively with ferric chloride indicating the presence of phenolic hydroxyl groups. Saponins and alkaloids were not detected. So far, there is not information about the presence of alkaloids and saponins in this specie.

Formic acid is a common modifier for reversedphase HPLC and its volatility also makes it highly suitable for mass spectrometry. This acid added in the mobile phase improved the ionization of the constituents and had shown not to alter the chromatographic retention time significantly (Colombo et al., 2006). The use of alternating positive/negative ionization modes during recording was preferred to ensure the assignment of the molecular weights. Table 1 list the retention times Rt, MS and MS/
MS data spectra and maximal UV wavelength $\left(\lambda_{\max }\right)$ of the constituents of this extract. As can be seen in Table 1 , a few constituents were extracted using this solvent system. Hydroethanolic extracts are more appropriate for extraction of more polar constituents, such as flavonoids glycosides, tannins and saponins and oxidized bitter acids, which could be more soluble in water. Besides this, the compounds that are present in trace quantities could not be analyzed due to low content.

Compounds characterization relied on UV spectra and reasonable molecular formulae calculated from mass measurements, both obtained from HPLCDAD-ESI-MS/MS analysis and comparison of these data with the metabolites previously reported for this specie and literature data (Verzele \& Keukeleire, 1991; GarciaVillalba et al., 2006; De Keukeleire, 2000). Combination of the UV and ESI data allowed the characterization of oxidation products of bitter acids, flavonoids and a procyanidin dimmer.

Table 1. LC/MS data, deprotonated and protonated molecular ions $(\mathrm{m} / \mathrm{z})$ for peaks, including the retention times (Rt), MS/MS experiments and maximal absorption wavelength $\left(\lambda_{\max }\right)$ of the constituents found in hydroethanolic extract of $H$. lupulus.

\begin{tabular}{|c|c|c|c|c|c|}
\hline Cmpd & $\begin{array}{c}\mathrm{Rt} \\
(\mathrm{min})\end{array}$ & $\begin{array}{c}\mathrm{UV} / \\
\text { vis Abs } \\
\lambda_{\max } \\
(\mathrm{nm})\end{array}$ & $\begin{array}{c}(\mathrm{M}-\mathrm{H})-/ \\
(\mathrm{M}+\mathrm{H})^{+} \\
(m / z)\end{array}$ & $\begin{array}{c}\mathrm{MS} / \mathrm{MS} m / z \\
(\mathrm{ESI}-)(\%)\end{array}$ & $\begin{array}{l}\text { Proposed } \\
\text { structure }\end{array}$ \\
\hline 1 & 5.6 & 260.0 & $635.0 / 637.0$ & $\begin{array}{c}534.9(40), \\
503.2(100), \\
293.1(30)\end{array}$ & $\begin{array}{l}\text { Unknown } \\
\text { compound }\end{array}$ \\
\hline 2 & 6.4 & ND & 191.0/-- & $\begin{array}{l}173.0(10), \\
111.1(100)\end{array}$ & Quinic acid \\
\hline 3 & 11.6 & 275.0 & $577.1 / 579.2$ & $\begin{array}{c}407.1(100), \\
425.0(90), \\
559.0(50), \\
451.0(30), \\
289.0(20)\end{array}$ & $\begin{array}{l}\text { Procyanidin } \\
\text { dimer }\end{array}$ \\
\hline 4 & 28.5 & $\begin{array}{l}255.0 \\
355.0\end{array}$ & $609.2 / 611.3$ & $301.0(100)$ & $\begin{array}{c}\text { Rutin } \\
\text { (quercetin-3- } \\
\text { O-rutinoside) }\end{array}$ \\
\hline 5 & 29.8 & 260.0 & 379.2/-- & $\begin{array}{c}180.1(100), \\
335.2(10), \\
361.1(10)\end{array}$ & $\begin{array}{c}\text { Oxidized } \\
\text { cohumulinone } \\
\text { derivative }\end{array}$ \\
\hline 6 & 31.1 & $\begin{array}{l}260.0 \\
355.0\end{array}$ & $593.1 / 595.2$ & $285.0(100)$ & $\begin{array}{c}\text { Kaempferol- } \\
3-O- \\
\text { rutinoside }\end{array}$ \\
\hline 7 & 32.5 & 260.0 & $393.2 / 395.2$ & $\begin{array}{c}348.2(100), \\
246.3 \\
(80), 195.1 \\
(70), 375.1 \\
(20),\end{array}$ & $\begin{array}{l}\text { Oxidized } \\
\text { humulinone } \\
\text { derivative }\end{array}$ \\
\hline 8 & 39.2 & ND & 317.5/-- & $\begin{array}{c}247.0(100), \\
179.1(60)\end{array}$ & Cohulupone \\
\hline 9 & 40.3 & ND & 263.5/-- & $\begin{array}{c}194.0(100), \\
126.1(20)\end{array}$ & $\begin{array}{l}\text { Hulupinic } \\
\text { acid }\end{array}$ \\
\hline
\end{tabular}

ND: The data were not determined 


\section{Characterization of phenolic compounds}

The peak at $5.6 \mathrm{~min}$ for compound $\mathbf{1}$, showed both deprotonated and protonated molecular ion at $\mathrm{m} / \mathrm{z}$ 635.0 and $\mathrm{m} / \mathrm{z}$ 637.0, respectively. The MS/MS spectrum exhibited pattern of fragmentation $\left([(M-\mathrm{H})-100]^{-}\right.$at $\mathrm{m} / \mathrm{z}$ 534.9, [(M-H)-132]- at $m / z 503.2$ and [(M-H)-342 $]^{-}$at $m / z$ 293.1; this compound probably is a tannin or a phenolic acid, but its characterization was not possible, due to absence of standard and literature data. Peak at $6.4 \mathrm{~min}$, characterized as quinic acid (2), showed deprotonated molecular ion at $\mathrm{m} / z$ 191.0, and its MS/MS spectrum showed a fragment ([(M-H)-18]' at $m / z$ 173.0.

Condensed tannins, consist of polyhydroxyflavan subunits with interflavonoid $C$ - $C$ linkages. Peak at $11.6 \mathrm{~min}$, probably procyanidin B1 (3), content of $9.0 \%$, exhibited deprotonated and protonated molecular ion at $\mathrm{m} / \mathrm{z} 577.1$ and $m / z$ 579.1, respectively. The MS/MS spectrum exhibited pattern of fragmentation $[(M-\mathrm{H})-18]^{-}$at $\mathrm{m} / z$ 559.0, $[(M-\mathrm{H})$ $126]^{-}$at $m / z$ 451.0, [(M-H)-152 $]^{-}$at $m / z$ 425.0, [(M-H)170] at $\mathrm{m} / \mathrm{z} 407.1,[(M-\mathrm{H})-288]^{-}$at $\mathrm{m} / \mathrm{z} 289.3$, typical of procyanidin dimer. Most beer proanthocyanidins carried a catechin as the terminal unit (Callemien \& Collin, 2008). The fragmentation reflects the oligomeric composition and the major fragment ions are due to the cleavage of the interflavonoid $C-C$ linkages with losses of catechin units (288 mass units). Retro-Diels-Alder (RDA) fission of the flavonoid nucleus gave rise to a fragment of $\mathrm{m} / \mathrm{z} 425.1$ from anion $\mathrm{m} / \mathrm{z}$ 577.1. This product $(\mathrm{m} / \mathrm{z} 425)$ eliminates water, probably from ring $\mathrm{C}$ in position $\mathrm{C}_{3} / \mathrm{C}_{4}$, resulting in a fragment ion of $m / z 407.0$ (Hellström et al., 2007). Procyanidin dimer exhibited absorption maximum at 275 nm.

The structural analysis of flavonoids was also accomplished by acid hydrolysis. The flavonoids were identified essentially on the basis of HPLC/DAD/ESI/ MS/MS analyses and a combination with HPLC behavior before and after acid hydrolysis. Comparison of the DAD chromatograms at $350.0 \mathrm{~nm}$ before and after hydrolysis, suggested that peaks at 28.5 and $31.1 \mathrm{~min}$, are flavonoid $O$-glycosides. These peaks showed UV/DAD $\lambda_{\max } 256.0$ and 356.0, typical of flavonols. Inspection of the UV spectra, which showed the maxima at around $355.0 \mathrm{~nm}$, confirmed the glycoside substitution at the 3 position of flavonols. Rutin, quercetin and kaempferol, were also identified by comparison with standard compounds and literature data. Rutin (4), content of $10.6 \%$, and kaempferol3 - $O$-rutinoside (6), content of $7.9 \%$, produced $[M-H-$ $308]^{-}$ion in the MS/MS spectra at $\mathrm{m} / \mathrm{z} 301.0$ (quercetin) and $m / z 285.0$ (kaempferol), respectively, suggesting the loss of a rutinose, corresponding to a rhamnose (146 mass units) plus a glucose (162 mass units) moiety (Table 1$)$. The combination of both ionization modes (positive and negative) gave extra certainty to the identity of quasimolecular ion. Because only the quasi-molecular ions are able to form adducts, clusters and/or molecular complexes with mobile phase species in the electrospray ionization source, their presence in the MS spectra is very useful to carry out the unequivocal identification of the $[\mathrm{M}+\mathrm{H}]^{+}$ ion and hence determining the molecular weight of the unknown compounds (Table 1). In this sense, the sodium adduct $[M+\mathrm{Na}]^{+}$at $22 \mathrm{amu}$ above the proposed quasimolecular ion is of a great relevance. The MS spectrum of rutin showed a $[M+\mathrm{H}]^{+}$ion at $m / z 611.3$ and a $[M+\mathrm{Na}]^{+}$ at $\mathrm{m} / \mathrm{z}$ 633.1, and kaempferol-3-O-rutinoside showed a $[M+\mathrm{H}]^{+}$ion at $m / z 595.2$ and a $[M+N a]^{+}$at $m / z$ 617.2. Although the aglycone and the glycane were all identified, the accurate structure of the flavonoids glycoside could not be always determined because identity and the site of connection of saccharide cannot be determined by $\mathrm{LC} /$ MS.

\section{Characterization of bitter acids}

Quantification of xanthohumol, $\alpha$ - and $\beta$-acids in hop samples had been done by using HPLC with UV or MS detection (Berwanger et al., 2005; Zanoli \& Zavatti, 2008; Kac \& Vovk, 2007). The cis- and trans-iso-alphaacids of isomerized $\alpha$-acids derivatives are known to have different UV-absorption spectra (Hughes, 2006). Nevertheless, UV is neither sensitive nor selective enough for the direct identification of minor hop acids in complex mixtures and MS detection proved to be superior to UV detection. The instability and structural similarity of bitter hop acids cause difficulty in routine analysis (Nikolic et al., 2005; Meissner \& Haberlein, 2006).

Bitter acids were mainly characterized by HPLCMS/MS. They are $\alpha$-acids with three major analogous (cohumulone $\mathrm{MW}=348$ and humulone/adhumulone $\mathrm{MW}=362$ ) and $\beta$-acids with three major analogous (colupulone $\mathrm{MW}=400$ and lupulone/adlupulone $\mathrm{MW}=414$ ) with a six-membered ring structure. Isomerization of $\alpha$-acids generated cis/trans-iso- $\alpha$-acids in a five member ring structure. The deprotonated molecular ion of the $\alpha$-acid humulinone is $m / z 377.2$, which corresponds to humulinone/adhumulinone (overlap), oxidation product of humulone/adhumulone. Cohumulone is an analogous of $\alpha$-acids (MW 348) and dihydroisocohumulone with MW 366 , is a product of oxidation with consequent reduction of side chain in cohumulone (Arraez-Roman et al., 2006). Iso- $\alpha$-acids can also be converted to reduced iso- $\alpha$-acids and three major types should be considered depending on the number of hydrogen atoms (dihydro, tetrahydro, hexahydro) incorporated during reduction (De Keukeleire, 2000). There are two types of dihydroiso- $\alpha$-acids. One is formed with a saturated isopentyl side chain and the other one is with a secondary alcohol $(\mathrm{C}-\mathrm{OH})$ on the isohexenyl side chain in substitution of ketone $(\mathrm{C}=\mathrm{O})$ on the iso- $\alpha$-acid moiety. Saturation of the double bonds leads to diminished reactivity and enhanced hydrophobicity (De Keukeleire, 2000). According to Howard \& Slater (1958), the reduced humulinone, known as tetrahydrocohumulinone showed 
UV maximum absorption peak at $270 \mathrm{~nm}$ in acidic ethanol.

Cohumulone and humulone were the most abundant bitter acids, while colupulone and lupulone were present in trace amounts in major part of hops (Foster et al., 2009). Both the $\alpha$ - and $\beta$-acids are very susceptible to oxidation and degradation during storage. Cohumulinone and humulinone are two corresponding oxidation products from $\alpha$-acids in five member ring structure. Likewise, there are cohulupone and hulupone the oxidation products from $\beta$-acids, corresponding to colupulone and lupulone/ adlupulone in five member ring structure. So they are still many pairs of other oxidation compounds. The structures of the oxidation products indicated that the lengths of the side chains in these compounds, together with the double bonds and hydroxyl groups, easily give rise to oxidation cyclizations leading to a five-membered structure (De Keukeleire, 2000; Garcia-Villalba et al., 2006). Cohumulinone is an oxidation product of cohumulone, and the conversion of humulone into humulinone is shown in Scheme 1.

This reaction is totally analogous to the important isomerization reaction of humulone to the isohumulones. The principal constituents obtained in this extract are oxidation products of bitter acids cohumulinone and humulinone. Peak at $29.8 \mathrm{~min}$, principal constituent (19.1\%), showed UV maximum absorption at $260.0 \mathrm{~nm}$, typical of iso- $\alpha$-acids derivatives (Intelmann et al., 2009) and exhibited deprotonated molecular ion at $\mathrm{m} / \mathrm{z} 379.2$ $\left(\mathrm{C}_{20} \mathrm{O}_{7} \mathrm{H}_{27}\right)$-, being probably an oxidized $\alpha$-acid derivative, tentatively identified as oxidized cohumulinone derivative (5) (Lupinacci et al., 2009). The MS/MS spectrum of 5 produced fragments $[(M-\mathrm{H})-18]^{-}$at $\mathrm{m} / \mathrm{z} 361.1$, attributed to the loss of water, [(M-H)-44] at $m / z 335.1$ and base peak [(M-H)-200]- at $m / z 180.1$, which was attributed to five-

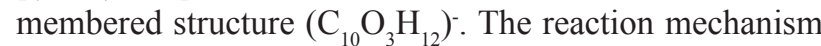
that could to explain the formation of cohumulinone derivative 5 proceeded via the oxidation of the 3-methyl2-butenyl side chains in cohumulinone, followed by cyclization, via either intramolecular dehydration or nucleophilic cleavage of the intermediate oxirane ring 10 (Scheme 1), indicating that two oxygen atoms were incorporated into cohumulone (Garcia-Villalba et al., 2006), whose posterior rearrangement could lead to compound 5, as shown in Scheme 1. Therefore, the formation of compound $\mathbf{5}$ could be explained due to the incorporation of two oxygen atoms into cohumulone. As it is seen from Table 1, negative ionization, compared with positive ionization, is more sensitive for most bitter acids characterization (Lupinacci et al., 2009).

The peak at $32.5 \mathrm{~min}$, other oxidized $\alpha$-acid found in high content $(16.3 \%)$, possess 14 mau higher than cohumulinone derivative $\mathbf{5}$, that correspond to one more $\left(\mathrm{CH}_{2}\right)$ group in the side chain, UV maximum absorption at $260.0 \mathrm{~nm}$ and deprotonated and protonated molecular ion at $m / z 393.2\left(\mathrm{C}_{21} \mathrm{O}_{7} \mathrm{H}_{29}\right)$ - and 395.2, respectively, being tentatively identified as an oxidized humulinone derivative. Compounds $\mathbf{5}$ and $\mathbf{7}$ showed similar pattern of fragmentation and MS/MS spectrum of 7 produced fragments $[(M-\mathrm{H})-18]^{-}$at $m / z \quad 375.1$, attributed to the loss of water, and the base peak $[(M-\mathrm{H})-45]^{-}$obtained at $m / z 348.2$ was attributed to the ion $\left(\mathrm{C}_{18} \mathrm{O}_{7} \mathrm{H}_{20}\right)^{-}$. Other important fragments [(M-H)-148]- were found at $m / z 245.3$ $\left(\mathrm{C}_{13} \mathrm{O}_{5} \mathrm{H}_{9}\right)^{-}$and $[(M-\mathrm{H})-198]^{-}$at $m / z 195.1\left(\mathrm{C}_{10} \mathrm{O}_{4} \mathrm{H}_{11}\right)^{-}$. It is very likely that humulinone represents the first step in the reaction sequence for formation of oxidized hop acid derivative 7. Oxidized $\alpha$-acids could be distinguished due to the base ion that correspond to the loss of $\left[\mathrm{CH}\left(\mathrm{CH}_{3}\right)_{2}\right]$.

The reaction mechanism that could to explain the formation of humulinone derivative 7 is the same for $\mathbf{5}$, as shown in Scheme 1. This oxidation product belongs to the abeo-isohumulone group, which is derived from isohumulones, but obtained directly through the oxidation of humulone. The differences among these two homologues occur only in side chain (cohumulinone $\left[\mathrm{R}=\mathrm{CH}\left(\mathrm{CH}_{3}\right)_{2}\right]$ and humulinone $\left(\mathrm{R}=\mathrm{CH}_{2} \mathrm{CH}\left(\mathrm{CH}_{3}\right)_{2}\right)$. The five-membered carbon ring (as in iso- $\alpha$-acids) is normally formed from $\alpha$-acids (six-membered ring) during the brewing process of beer (Lupinacci et al., 2009). Compounds 5 and 7 correspond to oxidized cohumulinone and oxidized humulinone/adhumulinone (isomers), respectively, being derived from cohumulone and oxidized humulone/ adhumulone, respectively, in which two oxygen atoms have been incorporated. In our case, the high temperature employed during the extraction procedure of the hop material might have caused isomerization of $\alpha$-acids into the corresponding iso- $\alpha$-acids. Oxidized cohumulinone and humulinone derivatives also were described in Humulus lupulus L., Cannabaceae, using UHPLC by Lupinacci et al. (2009).

The peak at $39.2 \mathrm{~min}$, compound $\mathbf{8}$, content of $9.3 \%$, exhibited the deprotonated ion at $\mathrm{m} / \mathrm{z} 317.2$ $\left(\mathrm{C}_{19} \mathrm{O}_{4} \mathrm{H}_{25}\right)^{-}$. MS/MS spectrum produced a base peak at $\mathrm{m} / \mathrm{z}$ 247.0 and a fragment at $\mathrm{m} / \mathrm{z} 179.1$, corresponding to the loss of two prenyl groups, with a constant neutral loss (69 amu) caused by removing of prenyl groups from the negative ion. Compound $\mathbf{8}$ was tentatively identified as cohulupone. Cohulupone (MW 318) is the oxidation product of $\beta$-acid colupulone, while hulupone is corresponding to lupulone/ adlupulone (overlap) with MW 332.0, their differences are due to one of the side chains (Haseleu et al, 2009a,b). Peak at $40.3 \mathrm{~min}$, content of $3.9 \%$, showed deprotonated molecular ion at $\mathrm{m} / \mathrm{z} 263.5$ and was tentatively identified as the $\alpha$-bitter acid, hulupinic acid (9). Hulupinic acid possesses the molecular formulae $\left(\mathrm{C}_{15} \mathrm{H}_{20} \mathrm{O}_{4}\right)$ and molecular weight at 264.0. The MS/MS spectrum exhibited the base peak at $\mathrm{m} / \mathrm{z} 194.0$ and a fragment at $\mathrm{m} / \mathrm{z} 126.1$ corresponding to the loss of two prenyl groups, which are characteristic of hulupinic acid (Haseleu et al., 2009a,b; Zhao et al., 2005). Hulupinic acid are also formed upon $\beta$-acid degradation (Haseleu et al., 2009a,b). The proposed structure of compounds 8 and $\mathbf{9}$ are shown in Figure 2. The isomers 
can be distinguished by their MS/MS fragmentation pattern, because the main product ion observed for $\alpha$-acids corresponds to one with the loss of a $\mathrm{C}_{5} \mathrm{H}_{9}$ side chain (69 $\mathrm{amu}$ ), whereas for iso- $\alpha$-acids mainly one with a loss of a
$\mathrm{C}_{6} \mathrm{H}_{8} \mathrm{O}$ side chain (96 amu) is observed (Lupinacci et al., 2009). As all of degradation products formed showed the isopropyl moiety, the generation seems to be independent of the variable alkanoyl side chain.

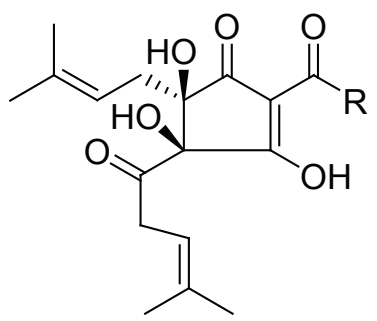

cohumulinone $\mathrm{R}=\mathrm{CH}\left(\mathrm{CH}_{3}\right)_{2}$ humulinone $\mathrm{R}=\mathrm{CH}_{2} \mathrm{CH}\left(\mathrm{CH}_{3}\right)_{2}$<smiles>[R]C(=O)C1=C(O)[C@]2(O[C@]3(C[C@H](O)C(C)(C)O3)C2=O)C(=O)C[C@@H]1C(C)C</smiles>

cohumulinone derivative $5 \mathrm{R}=\mathrm{CH}\left(\mathrm{CH}_{3}\right)_{2}$ humulinone derivative $7 \mathrm{R}=\mathrm{CH}_{2} \mathrm{CH}\left(\mathrm{CH}_{3}\right)_{2}$

Scheme 1. Formation of oxidized alfa-acids: the cohumulinone derivative $\mathbf{5}$ and the humulinone derivative 7.<smiles>CC(C)=CCC1(CC=C(C)C)CC(C(=O)C(C)C)=C(O)C1=O</smiles>

8<smiles>CC(C)=CCC1(CC=C(C)C)C(=O)C(O)=C(O)C1=O</smiles>

9
A combination of HPLC-DAD method with on-line MS provided the structural characterization of the constituent of hydroethanolic extract of H. lupulus, and this technique was fast, sensitive and required only minor sample preparation. On the other hand, the complete elucidation of complex plant secondary metabolites frequently requires the aid of more effective auxiliary techniques, such as nuclear magnetic resonance.

\section{Pharmacological results}

Regarding both pharmacological tests for anxiety, our data showed that the hydroethanolic extract of $H$. lupulus significantly $(p \leq 0,05)$ increased the time of permanence on the open arms of the EPM with all doses tested (with respective decreased on the closed arms) when compared with the control group, but did not affected the number of entrances on both open and closed arms; at the neophobia test, the $H$. lupulus extract also increased 
significantly the amount of food intake during the $60 \mathrm{~min}$ of evaluation. Diazepam and Passiflora incarnata, used as positive control also have shown the expected anxiolytic effect in both tests (data regarding the 2 tests not shown).

\section{Correlation among anxiolytic activity and chemical constituents}

Anxiolytic plants may interact with either glutamic acid decarboxylase (GAD) or GABA transaminase (GABA-T) and ultimately influence brain GABA levels and neurotransmission (Awad et al., 2007). Flavonoids have recently increased in importance because they have been identified as a new type of ligand with in vivo anxiolytic properties. The flavones chrysin and apigenin, obtained from medicinal plants, have shown an anxiolytic effect in rodents exposed to behavioral tests. Apparently, these compounds modulate the $\gamma$-aminobutyric acid (GABA) ergic system to produce the biological effect (Herrera-Ruiz et al., 2008). However, only a low content of flavonoids was found in this hydroethanolic extract.

H. lupulus is traditionally used as sleeping aids and probably acts via a central adenosine mechanism, which is possibly the reason for its sleep-inducing andmaintaining activity (Schiller et al., 2006). Hops showed significant inhibition of GAD activity (Awad et al., 2007). H. lupulus extracts induced the response of the ionotropic (GABAA receptors) (Aoshima et al., 2006) and its fraction containing $\alpha$-acids: in dose-dependently prolonged pentobarbital induced sleeping time (Zanoli et al., 2005). Xanthohumol had been reported as modulator of the GABAA receptor response (Meissner \& Haberlein, 2006). A research group had attributed the sedative effect of hops to 2-methyl-3-butene2-ol, derived from hop constituents during storage but probably also formed in vivo by metabolization of $\alpha$-acids. This compound, when intraperitoneally injected in rats, reduced motility without inducing a myorelaxant effect (Zanoli et al., 2007; Heinrich et al., 2004). However, according to Schiller et al. (2006), this compound cannot be the constituent responsible for the sedating activity of hop preparations.

Anxiolytic activity of hops had been attributed to three categories of constituents found in its extracts. Though the alpha-bitter acids proved to be the most active constituents, the beta-bitter acids and the hop oil clearly contributed to the sedating activity of hop extracts (Schiller et al., 2006; Zanoli et al., 2007). According to Zanoli \& Zanatti (2008), $\alpha$-acids fraction can be considered as the major responsible constituent for the enhanced pentobarbital effect and for the antidepressant property observed after the administration of hop extract. The $\beta$-acids fraction exerted an antidepressant activity as well, but reduced pentobarbital hypnotic activity (Zanoli et al., 2007; Zanoli \& Zanatti, 2008). Hydroethanolic extract analyzed in this study exhibited anxiolytic activity (data not shown), which could be attributed to the high content of oxidized bitter acids, that seems to be high enough to contribute to anxiolytic activity of this extract and thus could be attributed to oxidized alfa-acids, such as, cohumulinone $\mathbf{5}$ and humulinone $\mathbf{7}$ derivatives presents in major concentration. Their biological effect could be explained by a reduction in the GABAergic activity, although the involvement of other neurotransmitter systems can not rule out.

This survey indicated that HPLC-ESI-MS/MS was an efficient and rapid method for characterization of constituents from this species, although sometimes the combination of MS and UV data could not provide sufficient information for the full and unambiguous structural elucidation without identical standard. However, there was no doubt that the use of this methodology facilitated the studies on distribution, and characterization of constituents from hydroethanolic extract of H. lupulus, for which could be suggested the anxiolytic property of this extract.

\section{ACKNOWLEDGEMENTS}

The authors would like thank the Dr. E.A Carlini (Cebrid/Unifesp) and Alessandra de Carvalho Ramalho (Central Analítica da Universidade de São Paulo. This work was supported by grants from Fundação de Amparo à Pesquisa do Estado de São Paulo and Associação Fundo de Incentivo à Psicofarmacologia (Unifesp).

\section{REFERENCES}

Aoshima H, Takeda K, Okita Y, Hossain SJ, Koda H, Kiso Y 2006. Effects of beer and hop on ionotropic gammaaminobutyric acid receptors. J Agric Food Chem 54: 514-2519.

Arraez-Roman D, Cortacero-Ramirez S, Segura-Carretero A, Contreras JAML, Fernandez-Gutierrez A 2006. Characterization of the methanolic extract of hops using capillary electrophoresis-electrospray ionization-mass spectrometry. Electrophoresis 27: 197-2207.

Awad R, Levac D, Cybulska P, Merali Z, Trudeau VL, Arnason JT 2007. Effects of traditionally used anxiolytic botanicals on enzymes of the gamma-aminobutyric acid (GABA) system. Can J Physiol Pharmacol 85: 933-942.

Berwanger S, Zapp J, Becker H 2005. 13C-Labelling of xanthohumol in hops cones (Humulus lupulus L.). Planta Med 71: 530-534.

Bohr G, Klimo K, Zapp, J, Becker H, Gerhauser C 2008. Cancer chemopreventive potential of humulones and isohumulones (Hops $\alpha$ - and iso- $\alpha$-acids): induction of NAD(P)H: quinine reductase as a novel mechanism. Nat Prod Comm 3: 1971-1976.

Callemien D, Collin S 2008. Use of RP-HPLC-ESI(-)-MS/MS to differentiate various proanthocyanidin isomers in lager beer extracts. J Am Soc Brew Chem 66: 109-115.

Carlini EA, Burgos V 1979. "Screening" farmacológico de ansiolíticos: metodologia laboratorial e comparação entre o diazepam e o clorobenzapam. Rev Assoc Bras Psiquiatr 


$$
\text { 1: 25-31. }
$$

Chacur C, Raymond R, Hipolide DC, Giugliano EB, Leite JR, Nobrega JN 1999. Immediate increase in benzodiazepine binding in rat brain after a single brief experience in the plus maze: a paradoxical effect. Neurosci Lett 269: 2932.

Chadwick LR 2006. The pharmacognosy of Humulus lupulus L. (hops) with an emphasis on estrogenic properties. Phytomedicine 13: 119-131.

Chen WJ, Lin JK 2004. Mechanisms of cancer chemoprevention by hop bitter acids (beer aroma) through induction of apoptosis mediated by faz and caspase cascades. J Agric Food Chem 52: 55-64.

Ciochina R, Grossman RB 2006. Polycyclic polyprenylated acylphloroglucinols. Chem Rev 106: 3963-3986.

Colombo R, Yariwake JH, Queiroz EF, Ndjoko K, Hostettmann $\mathrm{K}$ 2006. On-line identification of further flavone C- and O-glycosides from sugarcane (Soccharum officinarum L., Gramineae) by HPLC-UV-MS. Phytochem Anal 17: 337-343.

Cowan PE 1977. Neophobia and neofilia: new-object and newplace reactions of the three ratus species. J Comp Physiol Psychol 91: 63-71.

De Keukeleire J, Janssens I, Heyerick A, Ghekiere G, Cambie J, Roldan-Ruiz I, Van Bockstaele E, De Keukeleire D 2007 Relevance of organic farming and effect of climatological conditions on the formation of alpha-acids, beta-acids, desmethylxanthohumol, and xanthohumol in hop (Humulus lupulus L.). J Agric Food Chem 55: 61-66.

De Keukeleire J, Ooms G, Heyerick A, Roldan-Ruiz I, Van Bockstaele E, De Keukeleire D 2003. Formation and accumulation of alpha-acids, beta-acids, desmethylxanthohumol, and xanthohumol during flowering of hops (Humulus lupulus L.). J Agric Food Chem 51: 4436-4441.

De Keukeleire D 2000. Fundamentals of beer and hop chemistry. Quim Nova 23: 108-112.

Diller RA, Riepl HM, Rose O, Frias C, Henze G, Prokop A 2007. Ability of prenylflavanones present in hops to induce apoptosis in a human Burkitt lymphoma cell line. Planta Med 73: 755-761.

Ennaceur A, Michalikova S, Van Rensburg R, Chazot PL 2008. Are benzodiazepines really anxiolytic? Evidence from a 3D maze spatial navigation task. Behav Brain Res 188: 136-153.

Foster BC, Kearns N, Arnason, JT, Saleem A, Ogrodowczyk C, Desjardins S 2009. Comparative study of hop-containing products on human cytochrome P450-mediated metabolism. J Agric Food Chem 57: 5100-5105.

Garcia-Villalba R, Cortacero-Ramirez S, Segura-Carretero A, Contreras JAML, Fernandez-Gutierrez A 2006. Analysis of hop acids and their oxidized derivatives and iso-alphaacids in beer by capillary electrophoresis-electrospray ionization mass spectrometry. J Agric Food Chem 54: 5400-5409.

Gerhauser C 2005. Beer constituents as potential cancer chemopreventive agents. Eur J Cancer 41: 1941-1954.

Hall AJ, Babish JG, Darland GK, Carroll BJ, Konda VR, Lerman RH, Bland JS, Tripp ML 2008. Safety, efficacy and antiinflammatory activity of rho iso-alpha-acids from hops Phytochemistry 69: 1534-1547.

Handley SL, Mithani S 1984. Effects of alpha adrenoceptor agonists in a maze exploration model of fear motivated behavior. $N$-S Arch Pharmacol 327: 1-5.

Haseleu G, Intelmann D, Hofmann T 2009a. Identification and RP-HPLC-ESI-MS/MS quantitation of bitter-tasting beta-acid transformation products in beer. J Agric Food Chem 57: 7480-7489.

Haseleu G, Intelmann D, Hofmann T 2009b. Structure determination and sensory evaluation of novel bitter compounds formed from beta-acids of hop (Humulus lupulus L.) upon wort boiling. Food Chem 116: 71-81.

Heinrich M, Barnes J, Gibbons S, Williamson EM 2004. Fundamentals of pharmacognosy and phytotherapy. Churchill Livingstone: Elsevier science limited.

Hellstrom J, Sinkkonen J, Karonen M, Mattila P 2007. Isolation and structure elucidation of procyanidin oligomers from saskatoon berries (Amelanchier alnifolia). J Agric Food Chem 55: 157-164.

Helmja K, Vaher M, Puessa T, Kamsol K, Orav A, Kaijurand M. 2007. Bioactive components of the hop strobilus: Comparison of different extraction methods by capillary electrophoretic and chromatographic methods. $J$ Chromatogr A 1155: 222-229.

Herrera-Ruiz M, Roman-Ramos R, Zamilpa A, Tortoriello J, Jimenez-Ferrer JE 2008. Flavonoids from Tilia americana with anxiolytic activity in plus-maze test. $J$ Ethnopharmacol 118: 312-317.

Howard GA, Slater CA 1958. The chemistry of hop constituents. The structure of humulinone. J Chem Soc 12: 14601462.

Hughes P 2006. Differences in the UV-spectra of the Hop-derived cis- and trans-iso-alpha-acids. J Am Soc Brew Chem 64: 47-51.

Intelmann D, Haseleu G, Hofmann T 2009. LC-MS/MS Quantitation of hop-derived bitter compounds in beer using the ECHO technique. J Agric Food Chem 57: 1172-1182.

Jaskula B, Goiris K, Van Opstaele F, De Rouck G, Aerts G, De Cooman L 2009. Hopping technology in relation to alphaacids isomerization yield, final utilization, and stability of beer bitterness. J Am Soc Brew Chem 67: 44-57.

Kac J, Vovk T 2007. Sensitive electrochemical detection method for alpha-acids, beta-acids and xanthohumol in hops (Humulus lupulus L.). J Chromatogr B 850: 531-537.

Khatib A, Kim HK, Wilson EG., Verpoorte R 2006. High performance liquid chromatographic method for isoalpha-acids. J Liq Chromatogr R T 29: 293-302.

Lee JC, Kundu JK, Hwang DM, Na HK, Surh YJ 2007. Humulone inhibits phorbol ester-induced COX-2 expression in mouse skin by blocking activation of NF-kappa B and AP-1: I kappa B kinase and c-Jun-N-terminal kinase as respective potential upstream targets. Carcinogenesis 28: 1491-1498.

Li HJ, Deinzer ML 2006. Structural identification and distribution of proanthocyanidins in 13 different hops. J Agric Food Chem 54: 4048-4056.

Lupinacci E, Meijerink J, Vincken, JP, Gabriele B, Gruppen H, Witkamp RF 2009. Xanthohumol from Hop (Humulus lupulus L.) is an efficient inhibitor of monocyte chemoattractant protein-1 and tumor necrosis factoralpha release in LPS-stimulated RAW 264.7 Mouse macrophages and U937 human monocytes. J Agric Food Chem 57: 7274-7281.

Magalhães PJ, Dostalek P, Cruz JM, Guido LF, Barros AA 2008. The Impact of a xanthohumol-enriched hop product on 
the behavior of xanthohumol and isoxanthohumol in pale and dark beers: a pilot scale approach. J Inst Brew 114: 246-256.

Meissner O, Haberlein H 2006. Influence of xanthohumol on the binding behavior of GABA (A) receptors and their lateral mobility at hippocampal neurons. Planta Med 72: 656658.

Mendes V, Monteiro R, Pestana D, Teixeira D, Calhau C, Azevedo I 2008. Xanthohumol influences preadipocyte differentiation: implication of anti proliferative and apoptotic effects. J Agric Food Chem 56: 11631-11637.

Mendes FR, Mattei R, Carlini EA 2002. Activity of Hypericum brasiliense and Hypericum cordatum on the central nervous system in rodents. Fitoterapia 73: 462-471.

Morris HV, Dawson GR, Reynolds DS, Atack JR, Stephens DN 2006. Both alpha 2 and alpha 3 GABA(A) receptor subtypes mediate the anxiolytic properties of benzodiazepine site ligands in the conditioned emotional response paradigm. Eur J Neurosci 23: 2495-2504.

Nikolic D, Li Y, Chadwick LR, Pauli GF, Van Breemen RB 2005. Metabolism of xanthohumol and isoxanthohumol, prenylated flavonoids from hops (Humulus lupulus L.) by human liver microsomes. J Mass Spectrom 40: 289299.

Schiller H, Forster A, Vonhoff C, Hegger M, Biller A, Winterhoff H 2006. Sedating effects of Humulus lupulus L. extracts. Phytomedicine 13: 535-541.

Schwekendiek A, Spring O, Heyerick A, Pickel B, Pitsch NT, Peschke F, de Keukeleire D, Weber G 2007. Constitutive expression of a grapevine stilbene synthase gene in transgenic hop (Humulus lupulus L.) yields resveratrol and its derivatives in substantial quantities. J Agric Food Chem 55: 7002-7009.

Segawa S, Yasui K, Takata Y, Kurihara T, Kaneda H, Watari J 2006. Flavonoid glycosides extracted from hop (Humulus lupulus L.) as inhibitors of chemical mediator release from human basophilic KU812 cells. Biosci Biotech Bioch 70: 2990-2997.

Stahl E 1969. Thin layer chromatography. A laboratory handbook. Berlin: Springer Verlag.

Stevens JF, Page JE 2004. Molecules of interest xanthohumol and related prenylflavonoids from hops and beer: to your good health. Phytochemistry 65: 1317-1330.

Van Cleemput M, Cattoor K, De Bosscher K, Haegeman G, De Keukeleire D, Heyerick A 2009. Hop (Humulus lupulus)derived bitter acids as multipotent bioactive compounds. J Nat Prod 72: 1220-1230.

Verzele M, De Keukeleire D 1991. Chemistry and analysis of hop and beer bitter acids. Amsterdam: Elsevier.

Vogel S, Heilmann J 2008. Synthesis, cytotoxicity, and antioxidative activity of minor prenylated chalcones from Humulus lupulus. J Nat Prod 71: 1237-1241.

Wagner H, Bladt S 1996. Plant drug analysis. A thin layer chromatography atlas. Berlin: Springer.

Xu YK, Yang SP, Liao SG, Zhang H, Lin LP, Ding J, Yue JM 2006. Alkaloids from Gelsemium elegans. J Nat Prod 69: $1347-1350$

Zanoli P, Zavatti M 2008. Pharmacognostic and pharmacological profile of Humulus lupulus L. J Ethnopharmacol 116: 383-396.

Zanoli P, Zavatti M, Rivasi M, Brusiani F, Losi G, Puia G, Avallone R, Baraldi M 2007. Evidence that the beta-acids fraction of hops reduces central GABAergic neurotransmission. $J$
Ethnopharmacol 109: 87-92.

Zanoli P, Rivasi M, Zavatti M, Brusiani F, Baraldi M 2005. New insight in the neuropharmacological activity of Humulus lupulus L. J Ethnopharmacol 102: 102-106.

Zhao F, Watanabe Y, Nozawa H, Daikonnya A, Kondo K, Kitanaka S 2005. Prenylflavonoids and phloroglucinol derivatives from hops (Humulus lupulus). J Nat Prod 68: 43-49. 